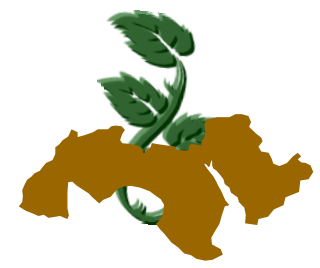

Arab Univ.

J. Agric. Sci.,

Ain Shams Univ.,

Cairo, 19(1), 171-178, 2011

\title{
CELLULASE PRODUCTION BY TWO FUNGAL STRAINS ISOLATED FROM TAIF IN SAUDI ARABIA
}

\author{
Nasr, Sohair ${ }^{1}$, A.; Nemmat ${ }^{2}$ A. Hussein; Abeer ${ }^{3}$ A. Abozaid \\ and Fawzia A. Al-salemi ${ }^{4}$
}

[12]

1- Dept. Microbiol., Fac. Agric., Ain Shams Univ., Egypt \& Dept. Biol., Fac. Sci.,Taif Univ., Saudi Arabia

2- Dept. Botany, Fac. Sci., Assiut Univ. ,Egypt \& Dept. Biol., Fac. Sci., Taif Univ., Saudi Arabia

3- Agric. Res. Cen., Cairo, Egypt \& Dept. Biol., Fac. Sci.,Taif Univ., Saudi Arabia

4- Biol. Dept., Fac. Sci., Taif Univ., Saudi Arabia

Keywords: Cellulases production, Alternaria alternata, Aspergillus wentii

\section{ABSTRACT}

Among 17 fungal isolates isolated from soil of El-hawia, El-hada, El-kaym and Karwa in Taif governorate in Saudi Arabia, two isolates showed high efficacy in producing cellulases enzymes. They were identified to be Alternaria alternata and Aspergillus wentii. Some factors such as carbon and wheat bran as a raw material, nitrogen, $\mathrm{pH}$ and incubation temperature were investigated. Results indicated that glucose and cellulose were the most effective as a carbon source while, urea was the best nitrogen source for cellulases production. Initial $\mathrm{pH} 5.0$ and incubation temperatures at 25 or $35 \circ \mathrm{C}$ achieved high cellulases production.

\section{INTRODUCTION}

Cellulose is the most abundant biomass on the earth. It is the main product of photosynthesis in terrestrial environments, and the most abundant renewable bioresource produce biosphere (100 billion dry tons/year).

Cellulose is commonly degraded by an enzyme called cellulase. This enzyme is produced by several microorganisms, commonly by bacteria and fungi (Bahkali, 1996; Magnelli \& Forchiassin, 1999; Shin et al 2000 and Immanuel et al 2006). Complete enzymatic hydrolysis of enzyme requires synergistic action of 3 types of enzymes, namely cellobiohydrolase, endoglucanase or carboxymethycellulase (CMCase) and $\beta$-glucosidases (Bhat, 2000). Cellulases are used in the textile industry for cotton softening and denim finishing; in laundry detergents for color care, cleaning and anti-deposition; in the food industry for mashing; in the pulp and paper industries for deinking, drainage improvement and fiber modification and they are even used for pharmaceutical applications (Kirk et al 2002 and Cherry \& Fidantsef, 2003).

\section{MATERIALS AND METHODS}

\section{Soil samples}

Calcareous soil samples were obtained from El-hawia, El-hada, El-Kaym and Karwa in Taif governorate in Saudi Arabia for isolation of fungi.

(Taif area found in Eastern province of Saudi Arabia, the landscape between Makkah and Taif, is littered with high mountains)

\section{Fungal isolates}

Seventeen fungal cultures were isolated from Taif governorate in Saudi Arabia.

\section{Media used}

Medium (1): Potato-Dextrose agar (Difco Manual, 1984). It was used for maintenance of fungi .It consists of Potatoe 200.0, Dextrose 20.0, agar $15 \mathrm{~g} \mathrm{/L}$, Distilled water $1000.0 \mathrm{ml}$ and $\mathrm{pH} 5.0$.

Medium (2): Czapeck,s Dox broth (Difco Manual, 1984). It has the following composition: Sucrose $30.0, \mathrm{~K}_{2} \mathrm{HPO}_{4} 1.0, \mathrm{KCl} 0.1$, $\mathrm{MgSO}_{4} .7 \mathrm{H}_{2} \mathrm{O} \quad 0.5, \quad \mathrm{FeSO}_{4} .7 \mathrm{H}_{2} \mathrm{O} \quad 0.01$, $\mathrm{NaNO}_{3} 3.0 \mathrm{~g} / \mathrm{L}$, Distilled water $1000.0 \mathrm{ml}$ and pH 5.0. 
This medium was modified by replacing glucose in the basal medium with addition of CMC in concentration of $10 \mathrm{~g} / \mathrm{L}$ as a substrate to produce cellulase enzyme.

\section{Fungal isolates identification}

Identification of the tested fungal isolates was accomplished depending on the morphological characters of fungi using KS 300 measuring program (Carl Zeiss Germany) for performing all measurements and comparing them with those that are present in the identification references (Gilman,1969 and Domsch et al 1980).

\section{Fungal inoculum preparation}

The fungi were maintained on potato dextrose agar slants at $4^{\circ} \mathrm{C}$. To prepare the inoculum, the spores on the slant were suspended in $2 \mathrm{ml}$ medium $\left(10^{6}-10^{7}\right.$ spores $\left./ \mathrm{ml}\right)$. This was used as the inoculum for the cellulases production medium.

\section{Cultivation}

The growth of the culture was carried out in $250 \mathrm{ml}$ Erlenmeyer flask containing $100 \mathrm{ml}$ medium no. 2 for fungal strains, supplemented with $\mathrm{CMC}$ as a substrate to produce cellulase enzyme. The flasks were sterilized at $121^{\circ} \mathrm{C}$ for $15 \mathrm{~min}$. The flasks were inoculated with $5 \%$ inoculum $(\mathrm{v} / \mathrm{v})$ transferred to the production medium, and then incubated on a rotary shaker (150 rpm). The broth after cultivation was used for enzyme studies. (Dien et al 2006).

\section{Enzyme assays procedures}

\section{Plate enzyme assay screening}

At the end of the incubation, the agar medium along with fungal colonies was flooded with an aqueous solution of Congo red $(1 \% \mathrm{w} / \mathrm{v})$ for 15 minutes. The Congo red solution was then poured off, and the plates were further treated by flooding with $1 \mathrm{M} \mathrm{NaCl}$ for 15 minutes. The formation of a clear zone of hydrolysis indicated cellulose degradation. The ratio of the clear zone diameter to colony diameter in $\mathrm{cm}$ was measured in order to select for the highest cellulase activity producer. The largest ratio was assumed to contain the highest activity (Howard et al 2003 \& Ariffin et al 2006). The data presented are average of three replicates.

\section{Carboxymethyl cellulose (CMC ase) activity}

CMCase activity was assayed using a method described by Mandels and Weber (1969). The activity was estimated using $1 \%$ solution of carboxymethlycellulose (CMC) in $0.05 \mathrm{M}$ citrate buffer $(\mathrm{pH} 4.8)$ as substrate. The reaction mixture contained $1 \mathrm{ml}$ citrate buffer, $0.5 \mathrm{ml}$ of substrate solution and $0.5 \mathrm{ml}$ of suitably diluted enzyme solution. The reaction was carried out at $50^{\circ} \mathrm{C}$ for $30 \mathrm{~min}$. One unit of CMCase activity was expressed as $1 \mu$ $\mathrm{mol}$ of glucose liberated per $\mathrm{ml}$ enzyme per minute.

\section{Filter-paperase (FPase) activity}

The activity of FPase was assayed according to the method explained by Mandels and Weber (1969). This method is similar to the CMCase assay method, but the substrate was Whatman No. 1 filter paper strip $(1 \times 6 \mathrm{~cm})$ soaked in $1 \mathrm{ml} 0.05 \mathrm{M}$ sodium citrate buffer $(\mathrm{pH} 4.8)$. The samples were incubated with $0.5 \mathrm{ml}$ enzyme solution at $50^{\circ} \mathrm{C}$ for $1 \mathrm{~h}$. One unit of FPase activity was determined as $1 \mu \mathrm{mol}$ of glucose liberated per $\mathrm{ml}$ enzyme per minute.

\section{$\beta$-Glucosidase activity}

One-tenth $\mathrm{ml}$ of the culture supernatant was incubated with $0.5 \mathrm{ml}$ of $0.05 \mathrm{M}$ acetate buffer $(\mathrm{pH} 5)$ containing $2.5 \mathrm{mg}$ cellobiose. After incubation at 50 ${ }^{\circ} \mathrm{C}$ for $10 \mathrm{~min}$ the glucose released was measured by the glucose oxidase peroxidase method (Zaldívar et al 2001).

\section{Determination of sugars}

The total amount of non-reducing sugars (as cellulose) was determined by the glucose oxidase peroxidase kit from (BIO-ADWIC) EL NASR PHARMACEUTICAL CHEMICALS Co. (Egypt).

\section{Effect of different carbon sources}

The appropriate carbon source was selected by replacing the original carbon substrate of the basal medium with equivalent carbon amount of each of the tested carbon sources (Glucose, Carboxymethycellulose, Cellobiose and Cellulose).Also, local raw material such as wheat bran (Cellulose $28 \%$, total nitrogen $4.8 \%$ ) was used as a source of carbon for cellulase production by the most efficient cellulase producing fungi. 


\section{Pretreatment of wheat bran (raw material)}

Wheat bran was pretreated with $4 \%$ solution of sodium hydroxide $(2000 \mathrm{ml} / 100 \mathrm{~g}$ substrate), autoclaved at $121^{\circ} \mathrm{C}$ for $30 \mathrm{~min}$. The material recovered by filtration, was washed with distilled water until neutralilty $(\mathrm{pH} 7.0)$ and dried at $65^{\circ} \mathrm{C}$ to constant weight.

\section{Effect of different nitrogen sources}

To detect the best nitrogen source for cellulase production by selected strains, the prescribed nitrogen source of the fermentation medium was replaced by equivalent nitrogen amount of each of the tested organic [Yeast extract, , Peptone, Urea] and inorganic $\left[\mathrm{NaNO}_{3}, \mathrm{NH}_{4} \mathrm{Cl} \&\left(\mathrm{NH}_{4}\right)_{2} \mathrm{SO}_{4}\right]$ nitrogen sources.

\section{Effect of initial pH}

Five values of $\mathrm{pH}$ ranged between 3.0 and 7.0 were chosen for studying their effects on cellulase enzyme to select the most suitable $\mathrm{pH}$ for cellulases production.

\section{Effect of incubation temperature}

To determine the optimum temperature for cellulases production, fermentation was carried out at various temperatures in the range of $20,25,28,35$ or $40^{\circ} \mathrm{C}$.

\section{Dry weight}

The mycelial dry weight or biomass from the liquid culture was determined by filtering off and washing the mycelium and drying it at $80^{\circ} \mathrm{C}$ for $24 h$.

\section{RESULTS AND DISCUSSION}

\section{Isolation of cellulase producing fungi}

A number of 17 isolates of fungi were isolated from different sources of soil from Taif governorate in Saudi Arabia. Screening of fungal isolates for cellulases activities was conducted by using Congo red test as a preliminary study for selecting the cellulases producers. After 7 days of incubation, all 17 fungal isolates showed signs of growth on CMC agar and demonstrated positive results in the Congo red test. Since the sole carbon source in CMC agar was carboxymethylcellulose (CMC), therefore the result of the test was a strong evident that cel- lulases were produced in order to degrade cellulose. The isolates were identified by morphological and taxonomic characteristics as genera of: Alternaria, Aspergillus, Fusarium, Rhizopus and Penicillium.

Data presented in Table (1) clearly show that Aspergillus sp. (10) and Alternaria sp. (17) were the most efficient genera selected according to the high ratio of clear zone diameter to colony diameter being 1.50 and 1.56 for Aspergillus sp. (10) and Alternaria sp. (17), respectively, and was selected for further studies. These results are in agreement with Peij et al (1998) who stated that filamentous fungi particularly Aspergillus and Trichoderma spp. are well known as efficient producers of cellulases. Mes-Hartree et al (1988); Hanif et al (2004) and Milala et al (2005) also reported that cellulase production was higher upon growth of Trichoderma harzianum and Aspergillus niger on cellulosic substrates.

Identification of the most efficient isolates in cellulase production

Identification of the fungal isolates was accomplished depending on colonial characters of the pure culture, microscopic characters and dimensions of informative character of each fungal isolate using a specific program for measurements Axio Vision 4.7 (with help of computerized Carl Zeiss microscope Axioplane 2) and comparing them with those that are present in the identification references (Gilman, 1969 and Domsch et al 1980).

\section{Effect of carbon source}

An experiment was carried out to investigate the effect of different carbon sources such as glucose, carboxymethycellulose (CMC), cellobiose, cellulose and wheat bran (as raw material) on the production of cellulase enzyme. Five carbon sources were used as shown in Table (2) .Data presented in Table (2) show that medium containing glucose gave the highest yield of cellulase activity being $2.244 \& 2.229 \mathrm{U} / \mathrm{ml}$ of CMCase, 2.228 \& $2.233 \mathrm{U} / \mathrm{ml}$ of FPase while, the medium containing cellulose gave the highest $\beta$ - glucosidases being 8.738 and $6.562 \mathrm{U} / \mathrm{ml}$ of by Alternaria alternata (17) and Aspergillus wentii (10), respectively. Regarding to the use of raw material as a sole source of carbon, in case of Alternaria alternata (17) ,the yield of the FPase enzyme was highest on wheat bran being $2.315 \mathrm{U} / \mathrm{ml}$. While, in Aspergillus wentii (10) the highest $\beta$-glucosidases being $3.158 \mathrm{U} / \mathrm{ml}$ on wheat bran. 
Table 1. Hydrolysis ratio of carboxymethycellulose (CMC) by fungal general incubated at $28^{\circ} \mathrm{C}$ for 7 days

\begin{tabular}{|c|c|c|c|}
\hline Fungal genera & $\begin{array}{l}\text { Growth diameter } \\
(\mathbf{c m})\end{array}$ & $\begin{array}{l}{ }^{*} \text { Cellulolysis diameter } \\
\text { (cm) }\end{array}$ & ${ }^{* *}$ Cellulolysis ratio \\
\hline \multicolumn{4}{|l|}{ 1- Alternaria } \\
\hline Alternaria sp. (1) & 1.0 & 1.2 & 1.2 \\
\hline Alternaria sp.(3) & 1.1 & 0.9 & 0.82 \\
\hline Alternarial sp. (4) & 1.2 & 0.8 & 0.67 \\
\hline Alternaria sp. (9) & 0.6 & 0.7 & 1.17 \\
\hline Alternaria sp. (11) & 0.8 & 1.0 & 1.25 \\
\hline Alternaria sp. (17) & 0.9 & 1.4 & 1.56 \\
\hline \multicolumn{4}{|l|}{ 2- Aspergillus } \\
\hline Aspergillus sp. (5) & 1.2 & 0.9 & 0.75 \\
\hline Aspergillus sp. (10) & 1.2 & 1.8 & 1.50 \\
\hline Aspergillus sp. (12) & 1.7 & 1.0 & 0.59 \\
\hline \multicolumn{4}{|l|}{ 3- Fusarium } \\
\hline Fusarium sp. (7) & 1.1 & 0.9 & 0.82 \\
\hline Fusarium sp. (8) & 1.5 & 1.1 & 0.73 \\
\hline Fusarium sp. (13) & 1.2 & 0.8 & 0.67 \\
\hline Fusarium sp. (14) & 0.8 & 0.5 & 0.63 \\
\hline Fusarium sp. (15) & 0.1 & 0.7 & 0.07 \\
\hline \multicolumn{4}{|l|}{ 4- Rhizopus } \\
\hline Rhizopus sp. (2) & 1.3 & 0.5 & 0.38 \\
\hline \multicolumn{4}{|l|}{ 5- Penicellium } \\
\hline Penicellium sp. (6) & 0.8 & 0.7 & 0.88 \\
\hline
\end{tabular}

${ }^{*}$ Cellulolysis diameter $=$ Clear zone diameter - Grwoth diameter

${ }^{* *}$ Cellulolysis ratio $=$ Cellulolysis diameter $\div$ Grwoth diameter

Table 2. Effect of carbon sources on production of cellulase enzyme by Alternaria alternata (17) and Aspergillus wentii (10) using shake flasks as a batch culture

\begin{tabular}{|c|c|c|c|c|c|c|c|c|}
\hline \multirow{3}{*}{$\begin{array}{l}\text { * Different carbon } \\
\text { * sources }\end{array}$} & \multicolumn{4}{|c|}{ Alternaria alternata (17) } & \multicolumn{4}{|c|}{ Aspergillus wentii (10) } \\
\hline & \multirow{2}{*}{$\begin{array}{l}\text { Biomass } \\
\mathrm{g} / 100 \mathrm{ml}\end{array}$} & \multicolumn{3}{|c|}{ Cellulase Activity (U) } & \multirow{2}{*}{$\begin{array}{l}\text { Biomass } \\
\mathrm{g} / 100 \mathrm{ml}\end{array}$} & \multicolumn{3}{|c|}{ Cellulase Activity (U) } \\
\hline & & CMCase & FPase & $\begin{array}{c}\beta- \\
\text { glucosidases }\end{array}$ & & CMCase & FPase & $\begin{array}{c}\beta- \\
\text { glucosidases }\end{array}$ \\
\hline Glucose & 0.506 & 2.244 & 2.228 & 2.746 & 0.603 & 2.229 & 2.233 & 5.373 \\
\hline $\begin{array}{l}\text { Carboxymethycellulose } \\
\text { (CMC) (Control) }\end{array}$ & 0.110 & 2.169 & 2.193 & 1.887 & 0.295 & 2.223 & 2.174 & 3.276 \\
\hline Cellobiose & 0.463 & 2.110 & 2.031 & 2.814 & 0.212 & 1.813 & 1.623 & 3.216 \\
\hline Cellulose & 0.412 & 2.205 & 2.155 & 8.738 & 0.397 & 1.914 & 1.470 & 6.562 \\
\hline Wheat bran & 0.315 & 1.963 & 2.315 & 2.121 & 0.204 & 1.352 & 1.259 & 3.158 \\
\hline
\end{tabular}


Table 3. Effect of nitrogen sources on the production of cellulase enzyme by Alternaria alternata (17) and Aspergillus wentii (10) using shake flasks as a batch culture

\begin{tabular}{|c|c|c|c|c|c|c|c|c|}
\hline \multirow{3}{*}{$\begin{array}{l}\text { Different } \\
\text { Nitrogen } \\
\text { Sources }\end{array}$} & \multicolumn{4}{|c|}{ Alternaria alternata (17) } & \multicolumn{4}{|c|}{ Aspergillus wentii (10) } \\
\hline & \multirow{2}{*}{$\begin{array}{l}\text { Biomass } \\
\mathrm{g} / 100 \mathrm{ml}\end{array}$} & \multicolumn{3}{|c|}{ Cellulase Activity (U) } & \multirow{2}{*}{$\begin{array}{l}\text { Biomass } \\
\mathrm{g} / 100 \mathrm{ml}\end{array}$} & \multicolumn{3}{|c|}{ Cellulase Activity (U) } \\
\hline & & CMCase & FPase & $\begin{array}{c}\beta- \\
\text { glucosidases }\end{array}$ & & CMCase & FPase & $\begin{array}{c}\beta- \\
\text { glucosidases }\end{array}$ \\
\hline Yeast extract & 0.408 & 0.972 & 0.014 & 1.285 & 0.359 & 2.247 & 2.012 & $1.157^{e}$ \\
\hline Peptone & 0.283 & 1.491 & 1.101 & 2.138 & 0.317 & 2.238 & 2.185 & 2.695 \\
\hline Urea & 0.310 & 2.241 & 2.252 & 6.857 & 0.286 & 2.266 & 2.247 & 7.870 \\
\hline $\mathrm{NaNO}_{3}$ & 0.292 & 2.235 & 2.244 & 4.981 & 0.267 & 1.627 & 2.028 & 5.424 \\
\hline $\mathrm{NH}_{4} \mathrm{Cl}$ & 0.344 & 2.232 & 2.187 & 4.395 & 0.285 & 2.160 & 2.204 & 5.459 \\
\hline$\left(\mathrm{NH}_{4}\right)_{2} \mathrm{SO}_{4}$ & 0.610 & 2.154 & 2.190 & 6.653 & 0.189 & 2.217 & 2.169 & 7.415 \\
\hline
\end{tabular}

Table 4. Effect of initial pH on the production of cellulase enzyme by Alternaria alternata (17) and Aspergillus wentii (10) using shake flasks as a batch culture

\begin{tabular}{|c|c|c|c|c|c|c|c|c|}
\hline \multirow{3}{*}{ Initial pH } & \multicolumn{5}{|c|}{ Alternaria alternata (17) } & \multirow{2}{*}{\multicolumn{3}{|c|}{$\frac{\text { Aspergillus wentii (10) }}{\text { Cellulase Activity }(\mathrm{U})}$}} \\
\hline & \multirow{2}{*}{$\begin{array}{l}\text { Biomass } \\
\mathrm{g} / 100 \mathrm{ml}\end{array}$} & \multicolumn{3}{|c|}{ Cellulase Activity (U) } & \multirow{2}{*}{$\begin{array}{l}\text { Biomass } \\
\mathrm{g} / 100 \mathrm{ml}\end{array}$} & & & \\
\hline & & CMCase & FPae & $\begin{array}{c}\beta- \\
\text { glucosidases }\end{array}$ & & CMCase & FPase & $\begin{array}{c}\beta- \\
\text { glucosidases } \\
\end{array}$ \\
\hline 3.0 & 0.209 & 2.169 & 2.193 & 1.887 & 0.098 & 2.202 & 1.887 & 4.495 \\
\hline 4.0 & 0.242 & 2.194 & 2.208 & 2.862 & 0.202 & 2.257 & 1.831 & 4.561 \\
\hline 5.0 & 0.312 & 2.261 & 2.245 & 4.988 & 0.368 & 2.631 & 2.031 & 5.488 \\
\hline 6.0 & 0.293 & 2.115 & 2.172 & 3.462 & 0.274 & 1.939 & 1.143 & 3.480 \\
\hline 7.0 & 0.288 & 2.008 & 2.079 & 3.120 & 0.262 & 1.082 & $1.036^{i}$ & 3.096 \\
\hline
\end{tabular}

Table 5. Effect of incubation temperature on the production of cellulase enzyme by Alternaria alternata (17) and Aspergillus wentii (10) using shake flasks as a batch culture

\begin{tabular}{|c|c|c|c|c|c|c|c|c|}
\hline \multirow{3}{*}{$\begin{array}{c}\text { Incubation } \\
\text { temperature }{ }^{\circ} \mathrm{C}\end{array}$} & \multicolumn{5}{|c|}{ Alternaria alternata (17) } & \multirow{2}{*}{\multicolumn{3}{|c|}{$\begin{array}{l}\text { Aspergillus wentii (10) } \\
\text { Cellulase Activity (U) }\end{array}$}} \\
\hline & \multirow{2}{*}{$\begin{array}{l}\text { Biomass } \\
\mathrm{g} / 100 \mathrm{ml}\end{array}$} & \multicolumn{3}{|c|}{ Cellulase Activity (U) } & \multirow{2}{*}{$\begin{array}{l}\text { Biomass } \\
\mathrm{g} / 100 \mathrm{ml}\end{array}$} & & & \\
\hline & & CMCase & FPase & $\begin{array}{c}\beta- \\
\text { glucosidases }\end{array}$ & & CMCase & FPase & $\begin{array}{c}\beta- \\
\text { glucosidases }\end{array}$ \\
\hline 20 & 0.174 & 2.217 & 2.144 & 1.410 & 0.136 & 1.446 & 2.185 & 2.151 \\
\hline 25 & 0.223 & 2.214 & 2.220 & 2.640 & 0.209 & 2.244 & 2.049 & 4.520 \\
\hline 28 (Control) & 0.297 & 2.231 & 2.256 & 4.977 & 0.276 & 2.661 & 2.102 & 5.312 \\
\hline 35 & 0.281 & 2.112 & 2.125 & 3.245 & 0.290 & 1.998 & 2.228 & 3.199 \\
\hline 40 & 0.201 & 2.002 & 2.109 & 3.200 & 0.205 & 1.824 & 2.061 & 2.239 \\
\hline
\end{tabular}




\section{Effect of nitrogen source}

To evaluate the effect of nitrogen source on cellulase formation, the nitrogen source in the basal medium was replaced by different nitrogen sources. Data revealed that the supplementation of organic and inorganic nitrogen sources stimulated the cellulase yield and activity. Using of organic $N$ sources responded in the positive cellulase activity more than the inorganic ones. Among the tested complex $\mathrm{N}$ sources, the effectiveness in supporting cellulase production and cellulolytic activity. Results recoded in Table (3) indicate that the sources of nitrogen greatly affected the production of cellulase enzyme. Urea was the best nitrogen source for Alternaria alternata (17) and Aspergillus wentii (10) giving $2.241 \& 2.266 \mathrm{U} / \mathrm{ml}$ of CMCase, 2.252 \& $2.247 \mathrm{U} / \mathrm{ml}$ of FPase and $6.857 \& 7.870 \mathrm{U} / \mathrm{ml}$ of $\beta$-glucosidases, respectively.

These results support the findings obtained by Ganguly and Mukherjee (1995) who studied the effect of nitrogen sources on the production of cellulases by Pencillium purpurogenum, where the organism enabled to use both inorganic and organic nitrogen sources for growth and production of the enzyme. Also, Spiridonov \& Wilson (1998) and Sun et al (1999) who found that $\mathrm{NH}_{4}$ compounds are the most favorable nitrogen sources for protein and cellulase synthesis.

\section{Effect of pH}

In Table (4), five values of $\mathrm{pH}$ ranged between 3.0 and 7.0 were chosen for studying their effects on cellulase production by Alternaria alternata (17) and Aspergillus wentii (10). The highest yield of cellulase activity being $2.261 \& 2.631 \mathrm{U} / \mathrm{ml}$ of CMCase, $2.245 \& 2.031 \mathrm{U} / \mathrm{ml}$ of FPase and 4.988 and $5.488 \mathrm{U} / \mathrm{ml} \beta$ - glucosidases by Alternaria alternata (17) and Aspergillus wentii (10), respectively on $\mathrm{pH} 5.0$. These results were in agreement with Coral et al (2002) who found that the CMCase activity of Aspergillus niger Z10 has a broad $\mathrm{pH}$ range between 3.0 and 9.0. The enzyme showed two major activity peaks at $\mathrm{pH} 4.5$ and 7.5. This result was probably due to the presence of two isoenzymes or subunits in the enzyme preparation.

\section{Effect of incubation temperature}

An experiment was conducted to find out the effect of different degrees of incubation temperatures ranged from 20 to $35^{\circ} \mathrm{C}$ on cellulase production by Alternaria alternata (17) and Aspergillus wentii (10). Results in Table (5) show that the temperatures from 25 to $35^{\circ} \mathrm{C}$ achieved high cellulase production in different degrees of incubation .These results are in agreement with Nipa et al (2006) who found that the optimum temperature for CMCase production by the fungus might lie between $27^{\circ}$ and $37^{\circ} \mathrm{C}$. While Muthuvelayudham and Viruthagiri (2006) reported that the maximum cellulase activity was obtained at $28^{\circ} \mathrm{C}$ by Trichoderma reesei.

In the present study, it could be concluded that carbon and nitrogen sources, $\mathrm{pH}$ values and incubation temperatures play an important role in the production of cellulase enzyme by Alternaria alternata (17) and Aspergillus wentii (10).

Acknowledgement: The authors are pleased to acknowledge Taif University, Saudi Arabia for supporting this work during the project No.710- 431- 1 in Faculty of Science (women).

\section{REFERENCES}

Ariffin, H.; N. Abdullah; M.S. Umi Kalsom; Y. Shirai and M.A. Hassan (2006). Productionand characterisation of cellulase by Bacillus pumilus EB3. Int. J. of Eng. \& Technol., 3(1): 47-53.

Bahkali, A.H. (1996). Influence of various carbohydrates on xylanase production by $V$. tricorpus. Bioresou. Technol., 33(3): 265 - 268.

Bhat, M.K. (2000). Cellulases and related enzymes in biotechnology. Biotech. Adv., 18(5): 355-383.

Cherry, J.R. and A.L. Fidantsef (2003). Directed evolution of industrial enzymes: an update. Curr. Opin. Biotechnol., 14 (4):438-443.

Coral, G.; B. Arikan; M.N. Unaldi and H. Guvenmez (2002). Some Properties of Crude Carboxymethyl Cellulase of Aspergillus niger Z10 Wild-Type Strain. Turk. J. Biol., 26: 209213.

Dien, B.S.; X.L. Li; L.B. Iten; D.B. Jordan; N.N. Nichols; P.J. O'Bryan and M.A. Cotta (2006). Enzymatic saccharification of hotwater pretreated corn fiber for production of monosaccharides. Enzyme \& Microbial Technol., 39(55): 1137-1144.

Difco Manual (1984). Dehydrated Culture Media and Reagents for Microbiology. $10^{\text {th }} \mathrm{Ed}$. DIFCO. Laboratories, Detroit, U.S.A.

Domsch, K.H.; W. Gams and T.H. Anderson (1980). Compendium of Soil Fungi. Vols. 1\&2. Academic Press. London. 
Ganguly, R. and S.K. Mukherjee (1995). Effects of different pure and complex carbon and nitrogen sources on production of cellulases by an isolated strain Penicillium purpurogenum. J. of Microbiol Biotechnol., 10(1): 47-58.

Gilman, J.C. (1969). A Manual of Soil Fungi. pp. 217-251. Indian Edition published by arrangement with the Original American Publishers, lowa State University Press, U.S.A.

Hanif, A.; A. Yasmeen and M.I. Rajoka (2004). Induction, production, repression and derepression of exoglucanase synthesis in Aspergillus niger. Bioresou. Technol., 94: 311319.

Howard, R.L.; P. Masoko and E. Abotsi (2003). Enzyme activity of a Phanerochaete chrysosporium cellobiohydrolase (CBHI.1) expressed as a heterologous protein from Escherichia coli. African J. Biotechnol., 2(9): 296-300.

Immanuel, G.; R. Dhanusa; P. Prema and A. Palavesam (2006). Effect of different growth parameters on endoglucanase enzyme activity by bacteria isolated from coir retting effluents of estuarine environment. Int. J. Environ. Sci. Tech. 3(1): 25-34.

Kirk, O.; T.V. Borchert and C.C. Fuglsang (2002). Industrial enzyme applications. Curr. Opin. Biotechnol.,13 (4): 345-351.

Magnelli, P. and F. Forchiassin (1999). Regulation of the cellulase complex production by Saccobolus saccoboloides, induction and repression by carbohydrates. Mycologia, 91(2): 359-364.

Mandels, M. and J. Weber (1969). The production of cellulases. In: Cellulases and Their Applications, pp. 391- 414. Hajny, G.J. \& E.T. Reese (eds), American Chemical Society, Washington DC.

Mes-Hartree, M.; C.M. Hogan and J.N. Saddler (1988). Influence of growth substrate on production of cellulase enzymes by Trichoderma harzianum E-58. Biotechnol. Bioeng., 31: 725-729.
Milala, M.A.; A. Shugaba; A. Gidado; A.C. Ene and J.A. Wafar (2005). Studies on the use of agricultural wastes for cellulase enzyme production by Aspegillus niger. Res. J. of Agric. \& Biological Sci., 1(4): 325-328.

Muthuvelayudham, R. and T. Viruthagiri (2006). Fermentative production and kinetics of cellulase protein on Trichoderma reesei using sugarcane bagasse and rice straw. African J. of Biotechnol., 5(20): 1873-1881.

Nipa, M.N.; S. Sultana and M. Abdul Hakim (2006). Induction of cellulase biosynthesis by cellobiose octaacetate in Aspergillus humicola. Bangladesh J. Microbiol., 23(2): 174176.

Peij, N.; M.M.C. Gielkens; R.P. Verles; K. Visser and L.H. Graff (1998). The transcriptional activator $X$ in $R$ regulates both xylanolytic endoglucanase gene expression in Aspergillus niger. Appl. Environ. Microbiol, 64(10): 3615-3617.

Shin, C.S.; J.P. Lee; P.S. Lee and S.C. Park (2000). Enzyme production of Trichoderma reesi Rut C-30 on a various lingocellulosic substrates. Appl. Biochem. \& Biotechnol. 8486: 237-245.

Spiridonov, N.A. and D.B. Wilson (1998). Regulation of biosynthesis of individual cellulases in Thermomonospora fusca. J. Bacteriol., 180(14): 3529-3532.

Sun, T.; B.H. Liu; Z.H. Li and D.M. Liu (1999). Effects of air pressure amplitude on cellulase productivity by Trichoderma viride SL-1 in periodic pressure solid state fermenter. Process Biochem., 34(1): 25-29.

Zaldivar, M.; J.C. Velásquez; I. Contreras and L.M. Pérez (2001). Trichoderma aureoviride T-121, a mutant with enhanced production of lytic enzymes: its potential use in waste cellulose degradation and/or biocontrol. Elect. J. of Biotechnol., 4(3): 160-168. 